Received: 22.6.2012.

Reviewed paper

UDK: 78.073-057.874"465.06/.09"

\title{
LISTENING TO MUSIC IN THE FIRST THREE GRADES OF PRIMARY SCHOOL
}

\author{
dr. sc. Jasna Šulentić Begić \\ The Teacher Faculty in Osijek \\ jsulentic@ufos.hr \\ mag. Katarina Tomljanović \\ Primary School Hugo Badalić \\ tomljanovic.katarina7@gmail.com
}

\begin{abstract}
Since school year 2006-2007 music lessons in primary schools have been carried out by the open model, which considers the music field of listening to music as a default activity. In fact, only active listening to quality music can empower pupils to critical and aesthetic evaluation of music and that is how they become competent users of musical culture. This paper reviews the thinking of different authors about listening to music as a teaching area and also research that was conducted in three different elementary schools in the city of Slavonski Brod during March 2012. In every elementary school music classes were observed in the first, second and third grade. Systematic observation led to the conclusion that some teachers still do not access to activity of listening to music in the artistic and aesthetic way, and that the music lessons continue to contain many tasks that are non-musical so pupils are encouraged to imagine non-musical content while listening to music, although the music itself is non-display art. It is important that teachers are aware of this fact so pupils can develop musical taste and a critical attitude towards music from an early age, which is the ultimate aim of teaching music.
\end{abstract}

Keywords: listening to music actively, open model, primary education 


\section{PREFACE}

Children meet with music from the earliest age. The interest and affection toward music most of the children show very early, and spontaneously make music and sing. The artistic competence that lies in all of us is more or less hidden, however it is present. Every child is an artist and shows talent, sense and even enthusiasm for creating certain type of music in it's own way (Supičić, 2006). Even if they notice child's tendency to music, parents often do not realize the importance of early musical development and activating musical disposition, but even do not know how to approach to it. A lot of research established that it could be influenced on aesthetic sensibility from the early age. "It is considered that the critical period for musical development is from three to six years old, so that's when the musical activities which could enhance that development should be planned" (Dobrota \& Curković, 2006, 108). "To wake the real interest in music in potential listeners of music, that it becomes their cultural heritage, childhood upbringing and the influence of cultural environment, especially in the family, are more important than the mere possibility of repeated and technical easily accessible listening to music through the mass media, where it can be heard or listened to more often" (Supičić, 2006, 213). However, most of the adolescent's free time occupies mass media through which a great extent of music is provided to them. But that is not enough for listeners, especially young ones, to understand it better as it cultural need, and at the end, from great choice do the right one. Musical messages broadcasted at the mass media do not affect only aesthetic receptivity, but several levels such as emotional, intellectual, physical and moral (same, 2006). Fun, popular music contains little artistic contents. It is "the music of feelings", everything is set to awake student's emotions (...) but as it is does not educate" (Šulentić Begić, 2006). Popular music broadcasted through the mass media contributes to more passive audience. From the earliest age the media occupies a lot of time in one's life, which could be very damaging. When one is overexposed and oriented to what others created that can bring to a state of constant passive observing, lower social activities and weaken the ability of critical judgement. Equally, to be used to omnipresence of "bad" music at the malls, restaurants, boutiques or work places destroys the opportunity of appropriate listening to musical works (Motte-Haber, 1999).

\section{CHILDREN'S MUSICAL PREFERENCES AND TASTE}

Taste can be defined as relatively stable long-term behaviour and evaluation, permanent dispositions that represent all one's preferences, and preferences are shortterm assessments of likes (Dobrota \& Curković, 2006). Along school, peers and the mass media, family is one of the most important factors at forming musical taste of children (same, 2006). Since attitudes toward music form during early childhood, the parent's attitude toward quality, art music is very important. Having positive attitude toward aesthetically valuable music, it is a great probability that their children are going to have the same. It has been determined that the percentage of children who value art music equals 
the percentage of parents who listen the same one (Šulentić Begić, 2006).

Dobrota and Ćurković (2006) researched musical preferences of fourth and eight class students and determined that most of them already visited theatre or concert hall. The question is weather this was due to imposed obligation or own will and interest, to which one should tend to. Here, of course, a great influence have teachers who should provide students visits to such institutions in order to make this activity will and habit in further life. Comparing fourth and eight class student's attitudes towards art music it has been concluded that most of the fourth grade students - $73 \%$, likes art music, while this percentage is lower with eight grade students $-38 \%$. Most of the eight grade students have troubling indifferent attitude towards art music. However, this is not the negative attitude from which Dobrota and Ćurković started, so the initial hypothesis that primary school students do not have positive attitude towards art music, was refuted. Only $4 \%$ of fourth grade and $5 \%$ of eight grade students declared that they have negative attitude towards art music. From these scores it can be concluded that art music is not strange to students, and that with lots of repetition it becomes more pleasant to listen to it, and this is the fact that should be used during planning lectures. Most of the fourth and eight grade students, more than $80 \%$, have CD players, but this information can be useful only if students actually use them for this purpose. Another assumption authors went to research is the fact that younger students are more open to new and unknown music. In order to investigate that, they used audio examples from romanticism (Tchaikovsky, Brahms) and 20th century (Bartok, Stravinski), and Egyptian and China folk music. Only $4 \%$ of students picked 20th century music as their favourite, while most of the students chose romanticism music - 51\% of fourth and $71 \%$ of eight grade students. Besides nature of the compositions, this information can be explained with the fact that this is the kind of music they came across the most through the classes, which is the most common reason of their choice. So it is obvious that Music lessons played significant part at positive evaluation of Tchaikovsky and Brahms. $45 \%$ students of fourth and $25 \%$ of eight grade students picked the "unknown" music of Egypt and China as their favourite. This confirmed the starting hypothesis that younger students are more open toward new and unknown music, while student's prejudices increase with age, which makes learning harder. To conclude, fourth grade students' preferences are equal in cases of "known" and "unknown" music, while only one quarter of eight grade students is inclined to unknown music.

Šulentić Begić (2009) did a research amongst eight grade students of one primary school in Osijek during school year of 2007/2008, where Music lessons are done by open model (central activity is listening to music) since school year 2004/2005. Results being processed, the author concludes that all children like listening to music. Popular music is what students like to listen the most, which they listen more than one hour a day, and that's why it is a good idea to place quality popular music in Music lessons to contribute development of musical taste and student's critical attitude. Art compositions that students prefer are those with nice and easily memorable melodies, which every teacher should know and take into consideration because he is the one who affects musical taste of students by choosing these compositions. Of course, students cannot and do not have 
to like all of the compositions provided for listening, but that does not mean he should gain a negative attitude toward the whole art music. Also, student's tendency toward listening to music rises with their age. Most of the students like to listen art music during Music lessons and think that it develops tendency toward art music and positively affects on their opinion on the same, although do not connect development of musical taste with listening to music by themselves. Most of the students listen to art music and have CDs that they get along the music students' books at home, and they think that is the reason why they started to like art music more (same, 2009).

Art, aesthetically beautiful music can be liked by constant and intensive listening. In today's teaching it is important to develop critical judgement and independence when making a decision, and also active participation in teaching process. However, critical judgement can be developed only if students acquaint different quality music. So, with developing interest in art music we develop student's musical taste, and enhance aesthetical upbringing. "It is the purpose of aesthetical upbringing to develop students' capability of observing, experiencing, evaluating and achieving wonderful" (same, 43). Sense of beauty itself is not innate, but it is developed with permanent aesthetical upbringing. When considering tasks of aesthetical upbringing, which is upbringing for beauty - even outside the boundaries of art - it can be concluded that the only teaching area in which aesthetical development can be possible is listening to music (Dobrota \& Curković, 2006).

Since attitudes toward music are formed in childhood, as mentioned before, teachers are obliged to make possible for students to make contact with art music, knowing and experience of music as art and receiving valuable musical experiences, so they would be more ready and flexible for further musical development (same, 2006).

\section{MUSIC LESSONS IN ELEMENTARY SCHOOL BY OPEN MODEL}

Before the open model was introduced in school year 2006/2007 in Music lessons, in all elementary schools teachers worked by integrative model, according to which musical literacy, singing by ear, play, musical creativity, listening to music and musicology facilities were prescribed. Rojko (1996) names this model scrapbook because non progress was made comparing to the previous one, but it turned Music lessons into doing a sort of a scrapbook which leads to failure. With only one Music lesson it was not possible to quality do all of the prescribed contents so they can be useful to them in their future life.

Unlike integrative, the activity of active listening to music and adopting musicological contents is the only default activity in open model, because only with listening, and not by one's own music making, can get to know great music, develop musical taste and critical relation towards music (same, 1996). Musicological contents include musical forms, folk music, vocal music, musical types, etc. Chosen activity, which may be singing, playing, working on a musical or something else, the teachers have the freedom to choose by their own inclinations or in agreement with students in accordance with their inter- 
ests. In these activities the process is more important than the outcome, because even only by participating in music students sharpen their skills and develop sensitivity to the music (Primary school curriculum, 2006). Due to the fact that the open model is based on the so-called reception model of teaching music with the emancipatory approach, it does not involve only listening to art music, but an extension of listening to all kinds of music, and as such it should affect students' critical attitude towards all kinds of music (Šulentić Begić, 2006).

According to research conducted by Šulentić Begić (2006) before the introduction of the open model, most of the students loved Music lessons and their favourite activity was singing, followed by listening to music, and the vast majority of students claimed that they did not like the music literacy. By the introduction of the open model musical literacy was not abolished, but the number of it's lessons has been reduced to a minimum, so that the pupils have the knowledge of this area at the level of recognition. After a year of working by the open the model again, a survey was carried out, and the results say that most students prefer the teaching according to the new, open model. Teaching became interesting to them, they liked the art music works they listened to, and the fact that the number of lessons of musical literacy was decreased, and the number of lessons devoted to singing increased.

While teaching music teachers should encourage active listening to music. The goal of active listening to music when teaching music is exploring music and the development of musical tastes, as content of listening is artistically valuable and aesthetically beautiful piece of music. Therefore, an active music listening, which is the default activity in the open model music lessons, students follow musical components such as contractors, tempo, dynamics, rhythm, measure, musical form, atmosphere, etc. These concepts students need to know without going into technical in detail. Active listening does not include lessons during which students sit motionless in their pews, but as the name says, they should be actively involved. Equally, the active involvement of the teachers is required. While listening to music teacher must not be doing anything else that would disrupt his or attention of the students while listening, and by own example show to the students how to listen to music. Students may be asked to move according to music, express their musical work experience and contribute to the creative musical activities, since children have a need to move with the music (Požgaj, 1988). Those can be spontaneous movements, imitating playing instruments, entry etc. Monitoring the movement with music and student's identifying musical elements and responding to music is one of the ways by which it is possible to examine the musicality of the students.

Before the listening it is important to prepare students for it, and this preparation should be primarily musical, so that listening to music can grow into experience. Preparing for listening should not consist of monotonous presentation of data on the work, the composer and / or historical period to which they belong. It is more important for students to grow in the audience who have the habit and by their own initiative listen to artwork, but to know to properly assess their historical place (Rojko, 1996). Due to didactical reasons, in order to facilitate to students listening to composition and as a preparation for the hearing, may be singing musical themes. This procedure will help students 
when handling the piece of music, which can represent abstract and complex material for them. Singing topics should not be difficult to pupils so they would not reject it from the composition before even hearing it. So instead of singing it is good that sometimes the teacher, who should be a skilled pianist, plays the characteristic passages from the compositions that they will listen (same, 1996).

Therefore, the teacher's task is to teach students how and what to listen to, and understand how and with what the composer made certain impression and experience. This can be achieved by assigning clear tasks (in conjunction with listening and appropriate to age of students) prior to listening so the students know what they need to focus their attention on while listening. Observing performers, rhythm, tempo, dynamics and monitoring topics are examples of simple tasks that can be given to students, which means that after a simple, students can move on to more complex tasks such as perception of musical forms, and successfully execute them. For example, in the first grade students may be asked to remember the title of repeatedly listened compositions and to recognize artists and voices, in the second grade with these tasks students should recognize the instrument which follows the melody, remember the name of the composer, set the tempo and dynamic compositions, and in the third grade they can still recognize the character and determine the parts of the composition, and recognize the certain composition among the more of them which are well-known to the students (Požgaj, 1988).

For the identification of all musical elements, and in order to experience and understand the compositions it is definitely required repeated listening, and between the two listening it is necessary to conduct a conversation with students about what they noticed, which should interest them and boost on further listening. After talking about the expressive elements of musical work, it should be rerun in its entirety and allow students to (if they want to) feel free to express their thoughts orally or in writing. However, questions like: "What does this music mean? What does it describe? What is it saying? What do you hear in it?" etc., are not desirable because they encourage the search of non-musical content in the composition and focus children's imagination and thinking in the wrong direction (Požgaj, 1988). Students must understand that the music is great for it's melodies, harmonies and other expressive elements, and not because of what it might describe.

Music is a non-display art and it does not show anything other than itself. "It is the duty of teachers to instruct the students in the music itself, to let them feel the beauty of the music as such, and to realize that it does not lie in any associations, images, imagining, reflections and emotions, but only in the music itself" (Rojko, 1996, 155). According to that, it should not be required from students to imagine non-musical content while listening to music, because this artistic and aesthetic listening to musical compositions will not be a problem for them.

Although there was a list of compositions for students to listen to in the 2006 Curriculum for primary schools, Rojko (1996) brings up the question of appropriateness of music for students' age, and points out that it is not true that students cannot listen to other compositions, too. It is considered that children are often underestimated by listening to compositions exclusively "for the children", such as Schumann's Album for the 
youth, because they are able to listen to almost any composition as long as it is presented to them in the right way. From the studies that have been conducted by Motte-Haber and Jehne, the conclusion was that the six year old children are already able to judge the music of different styles and evaluate high art music because they are not contaminated with pop music (1976 by Rojko, 1996). Besides, children of the age five to seven already have the option of establishing affective and cognitive attitude towards music and can distinguish musical passages without difficulty with different dominating marks (Keller, 1978 by Rojko, 1996).

Listening to music may be different considering the objective, content and activity of the listener (Rojko, 1996). Everything that is content of teaching Music should also be content of listening because music knowledge has to be adopted on the basis of active listening. Therefore, one should make all generalizations on the basis of listening. Emotional and thinking activity in the process of listening to music is going on at the same time, and one or the other may be more pronounced, depending on the preferences and attention of listeners (Požgaj, 1988). Content of listening when teaching Music, which is performed with the intention to know and experience the music as an form of art, can only be a work of art or performed live with the help of music playback device (such as a CD player or computer and speakers) (Rojko, 2006). Therefore, the conclusion is that nursery rhymes and folk music performed by the vocal and instrumental ensembles are not suitable for this kind of listening, but such musical examples can be sang or listened for the didactical reasons. Some folk songs may be the subject of active listening only in the finest artistic interpretations.

It is advisable to listen to compositions several times during the school year in order to keep it in the students' awareness of, and one should keep in mind that each new listening leads to new insights about the songs (Njirić, 1994). Also, listening to some compositions can be repeated in the next lesson. The thing that should be achieved through teaching Music and active listening to music is the student's objective knowledge of art music, and not necessarily and liking (Rojko, 1996).

\section{THE RESEARCH}

The study was done in three different elementary schools in the city of Slavonski Brod during March 2012. In each elementary school there were observed Music lessons in the first, second and third grade. Research included systematic observations of nine teachers (eight female and one male) of primary education during their teaching of $\mathrm{Mu}$ sic. Course of each hour was recorded in research journal. The purpose of the research was to monitor the implementation of the activities of listening to music in the teaching of music in the first three grades of primary school. Therefore, this study was to answer the following questions: Is the music that they are listening to during the Music appropriate to their age? Do they like to listen compositions? Do the teachers carry out active listening to music? How do they do it?. 


\section{INTERPRETATION OF THE RESEARCH RESULTS}

The starting points of this research were the research questions. The interpretation is based on the responses that have arisen on the basis of analysis of the research diary in which where recorded during the classes of musical culture in the first, second and third grade of elementary school.

\section{Is the music that they are listening to during the Music lesson appropriate to their age?}

Although they are most present in the teaching of primary education, we should not be afraid that the students can listen to some of the other composition except Schumann's Album for the young or The Carnival of the Animals by C. Saint-Saëns. Indeed, each composition, if it is presented in the right way, students are able to access it aesthetically and artistically and they can be listened to in elementary school (Rojko, 1996). Some compositions may not be appropriate to students because of their length, but that is not the reason for the underestimation of students potential to listen to music. Guided by these facts, we can conclude that the teachers, by knowing all of their students, should determine the appropriateness of the composition. Even if the students can not accurately identify all the musical components or form, you should not insist on accuracy because these tasks are tricks with wich teachers achieve students' motivation to listen to music. So, the most important task of the teacher is to achieve the students' active listening. Sims (1990) points out that it is important selection of the compositions and their length should be adapted to the students' age. Teachers should play shorter compositions to younger pupils and gradually play them in order to listen longer compositions. Analyzing the Music lessons in the first three grades of elementary school can be seen that all the compositions that the students listened to are appropriate to their age and they were able to access them artistically and determine all musical components. The exception was the musical tale Peter and the Wolf which can be observed as, although divided into two parts, due to its long duration for most of the students was too demanding for tracking.

\section{Do students like to listen to compositions?}

Attendance to musical lessons in the first three grades of elementary school was observed in a way that students were primarily enjoying activity of listening to music. Most of the students' experiences, enjoyment, pleasure and joy when listening to musical compositions are reflected with the different movements. This is a sign that confirms that students really can hear the music. Students with interest get to know not just new compositions but also the sounds and tones of various instruments. Woody (2004) points out that we should not expect from the younger students to sit motionless during listening activities, but that we should allow them to move with the music, which means to allow them to do some physical movement to mark the music phenomenon. It is believed that 
listening to music, during which students of younger school age must sit motionless, will be boring to them.

\section{Do the teachers carry out active listening to music?}

Campbell (2005) believes that listening to music is "the heart and soul of musical education". Pedagogy of listening has multiple aspects and they all require a great teacher involvement. Active listening requires good preparation for the teacher in relation to the content of the music compositions. While listening to music students needs to be encouraged with questions, gestures, etc. Active listening will lead to a deeper understanding and learning about music. We have noticed that teachers implemented students to actively listen to music in a way of determining the musical component. However, one full lesson of Music is dedicated to listening music story Peter and the Wolf, and that's why it is not spent as actively listening to music. Although divided into two parts, the duration of this story was too long for students, and despite the default assignment most students until the end of the lesson was not listening to music or the story. Students did not listen to complete musical story during the school lesson, but it was left as a task for homework, which they were supposed to do in the presence of parents. But after the Music lesson we should not assign a specific homework to students. Besides, who can claim with certainty that all parents are competent to perform this task, and ultimately, it is the duty of teachers. Though the program foresees listening to music story Peter and the Wolf by Sergei Prokofiev, such stories should not belong to the Music lessons or listening to music children listen to music only by the way because of the music scenes as their attention is drawn to the content of the story. Music stories accustom students to passive listening and are appropriate for preschool children only (Rojko, 1996).

\section{In what way do the teachers carry out active listening to music?}

In practice we encountered methodical process of verbal motivation with which it is not possible to create a musical motivation for student to hear, experience and know a new fact or deepen the well-known one. Methods of conversation, storytelling and (non-musical) demonstrations that don't have aesthetic or educational performance, are often used as motivation, rather than musical motivation like musical rhythm (nursery rhymes, rhythm game), hearing game (sounds and / or tones), games including musical dynamics or musical tempo, hearing and recognition of famous compositions, musical instruments or voices. McAnally (2007) points out that students should be motivated to listen compositions by the tasks related to the identification of musical elements. Students can track musical form while listening to the compositions using graphic display. Listening should be guided by, whether it is a teacher or a proficient student. Students observe themes, musical instruments and count how many times the recurring theme song appears (which was introduced earlier) etc. From attendance to the Musical lessons we have found that listening to music can be implemented as a second part of the main 
part of the lesson, or ran in the end of the lesson as the repetition of well-known compositions, which are typically carried out in the form of a quiz. Although the task of teachers was to instruct students in the music itself and let them feel the beauty of the music as such and realize that it does not lie in any associations, images, imagining, reflections and emotions, but only in the music itself (Rojko, 1996), this was not always the case in teaching practice. Specifically, we have noticed that all the teachers give assignments to students not just to determine the musical components, but they also impose imagining non-musical content, especially in compositions that have non-musical title, like the Flight of the Bumblebee by N. Rimsky-Korsakov. One should not forget the fact that the instrumental piece, regardless of the non-musical headline acts at the audience - in this case the students, with their expressive elements.

\section{CONCLUSION}

The aim of teaching Music is to raise competent and critical listeners and connoisseurs of music, and the task is listening to and learning about music in general and in particular musical works of art, and on this basis, the development of musical taste (Rojko, 1996). To achieve this, first of all the teacher must be able to determine that a piece of music is not on the appropriate artistic level. This is the category of secondary or trivial music, in which a natural musical tone is undermined with pointless and incomprehensible text of the song, or the natural tones are replaced with synthetic tones and sounds. Of course, one cannot say that this is the category of all the works of contemporary music and one that is not signed by famous composers. Therefore, the teacher needs to teach students, through teaching Music culture and proper methodological procedures, critical access to every piece of music. This can be achieved only and exclusively by systematic and constant listening to art music, and therefore listening to music is obligatory and the main area of the open model, which is used in elementary music lessons from the school year 2006-2007.

A survey conducted in the first three grades of elementary school showed that enough time or attention is not devoted to the music field of listening to music, and that it is still not in the middle of teaching Music. Although students are intrinsically motivated to music fields of singing and playing, these cannot be the main activities of teaching music because as such they do not have musical and artistic justification. Therefore, teachers need to become aware of the importance of the music field of listening to music in order to help students to manage and access critical variety of music that they are daily exposed to. Listening to music is extremely important because, especially with children under school age, it encourages aesthetic and cultural education as well as developing musical taste of the students. This means that students who are well guided in listening to appropriate compositions will develop a sense of observation for expressive elements of the compositions and it's evaluation, as well as the constant need for listening to high-quality, valuable music. "Teaching music must prepare students for life, that is to train them to during, but also after school, be a competent user of musical culture. In today's flood of 
all kinds of music this is extremely important" (Primary school curriculum, 2006, 66).

\section{BIBLIOGRAPHY}

1. Campell, P. S. (2005). Deep Listening to the Musical World. Music Educators Journal. 92(1): 30-36.

2. Dobrota, S. \& Ćurković, G. (2006). Glazbene preferencije djece mlađe školske dobi. Život i škola, 15-16: 105-114.

3. McAnally, E. A. (2007). Meaningful Listening for Middle and High School Students. Teaching Music, 15(1): 22.

4. Motte_Haber, H. de la (1999). Psihologija glazbe. Jastrebarsko: Naklada Slap.

5. Nastavni plan i program za osnovnu školu (2006). Zagreb: Ministarstvo znanosti, obrazovanja i športa.

6. Njirić, N. (1992). Pjevanka: priručnik za učitelje s metodičkim uputama za nastavu glazbene kulture u prvom, drugom i trećem razredu osnovne škole. Zagreb: Školska knjiga.

7. Požgaj, J. (1988). Metodika nastave glazbene kulture u osnovnoj školi. Zagreb: Školska knjiga.

8. Rojko, P. (1996). Metodika nastave glazbe: teorijsko - tematski aspekti. Osijek: Sveučilište Josipa Jurja Strossmayera. Pedagoški fakultet.

9. Sims, W. L. (1990). Sound Approaches to Elementary Music Listening. Music Educators Journal, 77(4): 38-42.

10. Supičić, I. (2006). Estetika europske glazbe. Zagreb: Školska knjiga.

11. Šulentić Begić, J. (2006). Primjena otvorenog modela nastave glazbe. Život i škola, 15-16: 97-104.

12. Šulentić Begić, J. (2009). Glazbeni ukus učenika osnovnoškolske dobi. Tonovi, 53: 65-74.

13. Woody, R. (2004). Reality-Based Music Listening in the Classroom: Considering Students' Natural Responses to Music. General Music Today, 17(2): 32. 